\title{
STATUS JEDNOTLIVCE VE SPRÁVNÍM PRÁVU
}

\author{
HELENA PRÁŠKOVÁ
}

\begin{abstract}
The Status of the Individual in Administrative Law
The article deals with the status of natural and legal persons, who are as the addressees of public administration one of the subjects of administrative-law relationship. In the introduction, the legal position (status) of a person is generally described. The following chapters then progressively examine legal personality, legal capacity, delictual liability, capacity to be party to proceedings and procedural capacity; that is capacity of individuals as well as legal entities. They focus on specificities of these types of capacity in the area of administrative law, on their legal regulation and on possible interpretation and application issues.
\end{abstract}

Keywords: legal personality; legal capacity; delictual liability; capacity to be party to proceedings and procedural capacity

Klíčová slova: právní subjektivita; způsobilost k jednání; deliktní způsobilost; způsobilost být účastníkem ř́zení a procesní způsobilost

DOI: $10.14712 / 23366478.2021 .35$

\section{1. ÚVOD}

Správněprávní vztahy se typicky uskutečňují mezi dvěma subjekty - na jedné straně je to subjekt, nositel veřejné správy, a na druhé straně adresát, jednotlivec, fyzická osoba nebo právnická osoba. Jedná se tedy o vztah mezi dvěma subjekty práva, mezi osobami v právním slova smyslu. Vykonavatel veřejné správy, ke kterému zákon vztahuje působnost $\mathrm{v}$ oblasti veřejné správy, $\mathrm{v}$ daném vztahu vystupuje jménem subjektu veřejné správy. ${ }^{1}$

Postavení nositelů veřejné správy a adresátů veřejné správy může být $\mathrm{v}$ určitých prrípadech relativní - ten, kdo je $\mathrm{v}$ jedněch vztazích nositelem nebo vykonavatelem veřejné správy, může být $\mathrm{v}$ jiných adresátem, a naopak. Např. je-li obec investorem nebo původcem odpadu, bude adresátem, jestliže ale její orgán rozhoduje o udělení živnostenského oprávnění nebo přijímá obecně závaznou vyhlášku, vystupuje jako subjekt

1 Srov. např. STAŠA, J. O vztazích správního práva. Acta Universitatis Carolinae Iuridica. 2010, Vol. LVI, č. 1, s. 49 a zde citovaná literatura. 
veřejné správy. Fyzická osoba nebo právnická osoba je zpravidla adresátem, může ale být též správním orgánem, pokud jí zákon svěří rozhodovací pravomoc - např. zdravotní pojišt'ovna při rozhodování o nárocích pojišstěnců nebo fyzická osoba v postavení myslivecké stráže nebo stráže ochrany prírody.

Ve veřejném právu, tedy ani ve správním právu, nenalezneme obecná ustanovení o subjektech správněprávních vztahů a o subjektech správního práva a jejich právním postavení. Je to dáno mj. tím, že správní právo není kodifikováno. Pouze v některých zákonech obecné části správního práva existuje dílčí úprava právního postavení osob např. v přsestupkovém zákoně.

Hlavní úsilí teorie správního práva je napřeno na popis, analýzu a vývojové tendence postavení subjektů veřejné správy a za ně jednajících vykonavatelů. Existuje poměrně bohatá literatura vztahující se $\mathrm{k}$ právnickým osobám veřejného práva, $\mathrm{k}$ nositelům tzv. impéria, jejich znakům, druhům, právní subjektivitě. ${ }^{2}$ Právnímu postavení druhého subjektu správněprávních vztahů - adresátů veřejné správy, tedy jednotlivců (fyzických a právnických osob) - není v současné teorii správního práva věnována větší soustředěná pozornost. Nauka se věnuje pouze některým aspektům jejich právního postavení, zejména ochraně subjektivních veřejných práv. Naproti tomu např. německá teorie správního práva se statusovými problémy jednotlivce zabývá a snaží se klasické učení o statusu rozvíjet ${ }^{3}$ a obohacovat o nové aspekty, zejména v souvislosti s evropskou integrací, ale též aktuálními problémy vyvolanými migrací, rostoucí participací jednotlivců na výkonu veřejné správy a plnění veřejných úkolů, smluvními formami výkonu veřejné správy, rozšiřováním pečovatelské veřejné správy apod.

Obecně je právní postavení (status) osoby charakterizováno především

1. právní subjektivitou - kterou se rozumí způsobilost nositele práv a povinností (subjektu) mít práva a povinnosti, způsobilost být subjektem práv a povinností, způsobilost stát se účastníkem právních vztahů,

2. způsobilostí k právně relevantnímu jednání, která zahrnuje

a) způsobilost vlastním jednáním vyvolat následky právem aprobované (dovolené),

b) způsobilost založit svoji odpovědnost, způsobilost nést nepříznivé právní důsled-

ky za své protiprávní jednání (deliktní způsobilost),

3. způsobilostí být účastníkem řízení a procesní způsobilostí,

4. subjektivními právy a povinnostmi.

2 Srov. např. KNAPP, V. O právnických osobách. Právnik. 1995, roč. 134, č. 10-11, s. 980-1001; BÁRTA, J. K některým otázkám subjektivity a sukcese právnických osob v platném právu. Právník. 1995, roč. 134, č. 2, s. 89-99; HENDRYCH, D. Právnické osoby veřejného práva. Správní právo. 1996, roč. XXIX, č. 1, s. 1-15; HENDRYCH, D. Právnické osoby veřejného práva a nový občanský zákoník. Acta Universitatis Carolinae Iuridica. 2003, Vol. XLIX, č. 1-2, s. 207-216; BERAN, K. Právnické osoby veřejného práva. Praha: Linde, 2006; BERAN, K. Pojem osoby v právu: osoba, morální osoba, právnická osoba. Praha: Leges, 2012.

3 Podle německé nauky začal používat termín ,status“ G. Jellinek, ten je také autorem klasické teorie právního postavení adresátů veřejné správy. JELLINEK, G. System der subjektiven öffentlichen Rechte. Herausgegeben von Kersten, J. 2. überarb. Aufl. Tübingen: Verlag von Mohr (Paul Siebeck), 2011; dále srov. např. MASING, J. Der Rechtstatus des Einzelnen im Verwaltungsrecht. In: HOFFMANN-RIEM, W. SCHMIDT-AßMANN, E. - VOßKUHLE, A. Grundlagen des Verwaltungsrechts. Band 1. 2. Aufl. München: C. H. Beck, 2012, s. 437 a násl.; STOBER, R. Die Rechtssubjekte des Verwaltungsrechts. In: WOLFF, H. J. - BACHOF, O. - STOBER, R. - KLUTH, W. Verwaltungsrecht. I. München: C. H. Beck, 2017, s. 363 a násl. 
Právní status jednotlivce má základ v individuu - tedy ve fyzické osobě, v člověku. Vychází z důstojnosti, svobody a rovnosti lidí, kteří jsou považováni za východisko i cíl ochrany a ř́idicí činnosti státu a za poslední instanci jakékoli jeho legitimity. ${ }^{4}$

Pojem právního postavení (právního statusu) osoby byl vypracován právní teorií a rozumí se jím rozsah a míra právní subjektivity a souhrn práv a povinností, které vznikají nebo mohou vzniknout osobě na základě zákona (práva, právního systému). ${ }^{5}$ Právní status osobě umožňuje, nebo ji naopak omezuje v tom, aby sledovala své vlastní zájmy. ${ }^{6}$ Hovoříme-li obecně o právním postavení osoby, pak se její status nevyčerpává v konkrétních, aktuálních právech a povinnostech, stejně tak se netýká pouze jednotlivých, určitých právních vztahů. Zahrnuje potenciální práva a povinnosti a možné právní vztahy, které se pak v různých aktuálních situacích mění, konkretizují a aktualizují. Právní status člověka neměl vždy podobu rovné a obecné právní způsobilosti s předem neomezenou možností mít práva a povinnosti, s potenciální možností vstupovat do všech právních vztahů. Souvisel s místem a postavením (statusem) osoby ve společnosti. Jako př́íklad je možné uvést postavení otroka v římském právu nebo rozdílný status osob podle stavovské př́slušnosti ve středověkém feudálním právu. ${ }^{7}$

Rozlišuje se zpravidla právní status obecný, speciální a individuální. Obecným statusem se rozumí to, co je společné právnímu postavení všech fyzických osob nebo právnických osob. Zvláštní status zahrnuje práva a povinnosti, které se vztahují ke skupinám osob charakterizovaným např. jejich služebním postavením, vlastnictvím určitých věcí, vztahem ke státu, veřejnoprávní korporaci nebo veřejné instituci, pracovním zařazením, dosaženou kvalifikací, dosažením určitého věku apod. Lze tedy hovořit např. o statusu cizince s povoleným přechodným nebo trvalým pobytem, ${ }^{8}$ statusu azylanta, ${ }^{9}$ statusu studenta veřejné vysoké školy, ${ }^{10}$ statusu podnikatele, statusu provozovatele určitého technického zařizení (odpadového, elektrického, plynového, komunikačního, dopravních

4 Srov. čl. 1 odst. 1 Ústavy a čl. 1 Listiny základních práv a svobod: „,Česká republika je svrchovaný, jednotný a demokratický právní stát založený na úctě k právưm a svobodám člověka a občana. "Srov. PRÁS̆KOVÁ, H. K právnímu postavení právnických osob. In: HANDRLICA, J. (ed.). Veřejné právo a soukromé právo: aktuální tendence a výzvy veřejnoprávni úpravy plynoucí z problematiky právního dualismu. Praha: Univerzita Karlova v Praze, Právnická fakulta, 2014, s. 76.

5 Srov. např. VEVERKA, V. - ČAPEK, J. - BOGUSZAK, J. Základy teorie práva. Praha: Aleko, 1991, s. 98 a násl.

${ }^{6}$ Srov. BERAN, K. - ČECH, P. - DVOŘÁK, B. - ELISCHER, D. - HRÁDEK, J. - JANEČEK, V. KÜHN, Z. - NOVOTNÁ KRTOUŠOVÁ, L. - ONDŘEJEK, P. Právní jednání a odpovédnost právnických osob po rekodifikaci českého soukromého práva. Praha: Wolters Kluwer ČR, 2018, s. 10.

7 Srov. např. HURDíK, J. Osoba a jeji soukromoprávní postavení v ménícím se světě. Brno: Masarykova univerzita, 2004, s. 30, 32; MALÝ, K. Dějiny českého a československého práva do roku 1945. Praha: Linde, 2005, s. 76-77; BERAN, K. Veřejnoprávní subjektivita. Právní rozhledy. 2004, č. 23, s. 855 a tam cit. literatura.

8 Takový cizinec má např. právo pobývat přechodně nebo trvale na území, zapojit se do programu národnostních menšin, za stanovených podmínek právo na zdravotní péči, právo studovat na střední a vysoké škole, povinnost hlásit místo pobytu na území a jeho změny, mít zdravotní pojištění, platit př́islušné daně a poplatky, strpět snímání daktyloskopických otisků a pořizování obrazových záznamů, aktuální pořízení biometrických údajů prováděné podle zákona o pobytu cizinců, posílat děti do školy apod.

9 Srov. zejména § 50 a násl. zákona č. 325/1999 Sb., o azylu.

10 Student veřejné vysoké školy má např. právo studovat zvolený studijní program, skládat předepsané kontroly studia, navrhovat téma kvalifikačních prací, používat zařízení a informační technologie vysoké školy, volit a být volen do akademického senátu, využívat sociální, daňové a jiné výhody, má povinnost dodržovat vnitřní předpisy vysoké školy, podléhá disciplinární pravomoci vysoké školy apod. 
služeb apod.), statusu státního zaměstnance, statusu stavebníka, statusu zdravotnického pracovníka, statusu spotřebitele, statusu mladistvého apod. Individuální status pak označuje souhrn obecných, speciálních a individuálních práv a povinností konkrétní osoby.

Z hlediska obsahu práv a povinností se zpravidla rozlišuje status negativus (právo na to, aby se veřejná správa zdržela zásahů do práv a svobod osob), status positivus (právo na určitou činnost nebo plnění veřejné správy) a status activus (právo podílet se na správě veřejných věcí). Šířeji se někdy zahrnuje též status processualis (zejména v souvislosti s právem na spravedlivý proces) a status europeans (reflektující právní postavení osob v unijním právu). ${ }^{11}$

Termín status osoby je používán také v jiném smyslu - jako označení osobního stavu. Osobní stav je souhrnem základních skutečností, znaků a právních vztahů, které osobu individualizují, charakterizují a umožňují ji rozlišit ve společenské realitě. Osobní stav osob upravuje zákon č. 89/2012 Sb., občanský zákoník (§ 9 odst. 1), blíže jej pak rozvádí ve své hlavě II, dále jsou věci osobního stavu upraveny v dalších zákonech. ${ }^{12}$ Mezi věci osobního stavu (tzv. statusové věci) patří především narození a smrt člověka, jméno, př́ijmení, pohlaví, vznik a zánik manželství nebo jiného právem uznaného partnerského vztahu, mateřství a otcovství, osvojení, státní př́íslušnost, svéprávnost a její omezení. Osobní stav nutno vztáhnout i na právnické osoby, kde se jím rozumí otázky založení, vzniku, zrušení, zániku právnické osoby. K rozhodování ve věcech osobního stavu jsou příslušné obvykle soudy, ${ }^{13}$ ve stanovených př́ipadech i správní orgány, ty rozhodují např. o udělení státního občanství České republiky nebo o změně jména a př́ijmení. Určení, zda v rozhodování jde o věci osobního stavu, je pro praxi důležité, protože se k tomu váží významné právní důsledky. Např. o otázkách osobního stavu si nemůže správní orgán učinit úsudek v rámci řešení prejudiciálních otázek, pravomocné rozhodnutí o osobním stavu má téměř vždy konstitutivní povahu s účinky ex nunc a je závazné pro každého, pravomocné rozhodnutí ve věci osobního stavu nelze přezkoumat v přzezumném ř́zení. ${ }^{14}$

\section{PRÁVNÍ SUBJEKTIVITA (PRÁVNÍ OSOBNOST)}

Právní subjektivitou, jak bylo již výše uvedeno, se zpravidla rozumí způsobilost nositele práv a povinností (subjektu) mít práva a povinnosti, způsobilost být subjektem práv a povinností, způsobilost stát se účastníkem právních vztahů. ${ }^{15}$ Právní subjektivita je přitom nezávislá na existenci právních vztahů, jichž by se osoba musela účastnit, představuje potenciální, nikoli reálnou způsobilost vstupovat do právních

11 Srov. např. STOBER, c. d., s. 368-370.

12 Srov. např. zákon č. 301/2000 Sb., o matrikách, jménu a př́ijmení; zákon č. 115/2006 Sb., o registrovaném partnerství; zákon č. 186/2013 Sb., o státním občanství České republiky.

13 Srov. řízení o tzv. statusových žalobách podle zákona č. 292/2013 Sb., o zvláštních řízeních soudních.

14 Srov. § 57 odst. 1 písm. c), § 73 odst. 2 a § 94 odst. 2 zákona č. 500/2004 Sb., správní řád (dále jen „správní řád“).

15 Srov. např. DVOŘÁK, J. - ŠVESTKA, J. - ZUKLÍNOVÁ, M. a kol. Občanské právo hmotné. 1, díl první, Obecná část. 2. aktual. a dopl. vyd. Praha: Wolters Kluwer ČR, 2016, s. 215; KNAPP, V. Teorie práva. Praha: C. H. Beck, 1995, s. 70 a násl.; BERAN, Veřejnoprávní subjektivita, s. 849 a násl. 
vztahů. Je to vlastnost subjektu práva, jehož abstraktní osobnost je právem vytvářena. Právní subjektivita je atributem právním, člověk nabývá způsobilosti k právům a povinnostem proto, že právní řád s jeho narozením takový účinek spojuje. ${ }^{16}$ Občanský zákoník proto v $\S 17$ odst. 1 stanoví, že ,, [p]ráva může mít a vykonávat jen osoba. Povinnost lze uložit jen osobě a jen vi̊či ní lze plnění povinnosti vymáhat. “

Je otázkou, zda způsobilost mít práva a povinnosti (právní osobnost) je obecná, či zda se liší subjektivita v právu soukromém a právu veřejném, nebo je odvětvová (liší se podle jednotlivých právních odvětví).

Mluvíme-li o obecné právní subjektivitě jako o obecném předpokladu pro nabývání konkrétních práv a povinností, pak lze zřejmě konstatovat, že u občanů (fyzických osob) není právní osobnost omezena jen na určité právní odvětví - není možné, aby občan mohl mít práva a povinnosti pouze v oboru práva občanského, a nemohl je mít v oblasti např. práva správního nebo finančního. Proto se nemluví o právní osobnosti občanskoprávní, trestněprávní, správněprávní, pracovněprávní apod., ale právní osobnost fyzické osoby je jednotná pro celý právní řád. Něco jiného je pak možnost vzniku konkrétních práv a povinností, zde zákony jednotlivých odvětví práva často stanoví různé náležitosti a předpoklady, za nichž se fyzická osoba může stát účastníkem právních vztahů určitého druhu, ${ }^{17}$ jako př́iklad je možné uvést pracovněprávní subjektivitu.

U právnických osob je situace složitější, může se stát, že zákony z oblasti veřejného práva ukládají povinnosti a stanoví práva i entitám, které z hlediska soukromého práva subjektem nejsou (viz dále). Veřejnoprávní subjektivita tak nemusí splývat se soukromoprávní subjektivitou. ${ }^{18}$

V. Knapp rozlišuje recipienty práva, tj. ty, na jejichž vůli a vědomí se právní norma obrací a působí (což může být pouze člověk, fyzická osoba), a adresáty, které vytváří, resp. definuje samo právo a vymezuje jejich právní subjektivitu (právní osobnost). Tu propůjčuje nejen člověku (fyzické osobě), ale též sdružení lidí, organizaci lidí, popřr. i účelově vymezenému majetku, a tím finguje právní osobnost subjektů odlišných od člověka a nazývá je osobami právnickými. ${ }^{19}$

Zajímavá je také otázka, zda může mít někdo jen způsobilost mít práva, nebo naopak jen způsobilost mít povinnosti. Zdá se, že logicky tomu tak být nemůže, protože osoba, která by měla jen povinnosti, by je zřejmě nemohla plnit bez (zejména majetkových) práv, a naopak. Uvádí se, že jediným myslitelným př́kladem subjektu způsobilého jen k právům je nasciturus. ${ }^{20}$

16 Srov. např. KNAPP, O právnických osobách, s. 981; K. Beran (Veřejnoprávní subjektivita, s. 854) k pojmu právní subjektivity shrnuje, že z hlediska právního řádu jako celku ,je každý právní subjekt

a) ,stvořen právním řádem",

b) povinen strpět, že mu právní rád stanoví rozsah způsobilosti k právům a povinnostem (subjektivitu), a c) z hlediska vlastní subjektivity stojí v nerovném povinnostním postavení vi̊či právnímu řádu“.

17 Např. BOGUSZAK, J. Utváření subjektivních práv: subjekty práva. In: BOGUSZAK, J. - ČAPEK, J. GERLOCH, A. Teorie práva. Praha: Eurolex Bohemia, 2001, s. 121: „K tomu, aby subjekt měl určitá subjektivni práva a povinnosti, musi být právní titul. “

18 Srov. např. BERAN, Veřejnoprávní subjektivita, s. 855, 857 a násl.; WEYR, F. O veřejnoprávní subjektivitě. In: Pocta k šedesátým narozeninám Dr. Emila Háchy. Bratislava: Právnická fakulta Univerzity Komenského v Bratislavě, 1932, s. 234 a násl.

19 Srov. KNAPP, Teorie práva, s. 70-71; KNAPP, O právnických osobách, s. 981.

20 Srov. např. PELIKÁN, R. Právní subjektivita. Praha: Wolters Kluwer ČR, 2012, s. 54; PRÁS̆KOVÁ, K právnímu postavení právnických osob, s. 82. 


\section{FYZICKÉ OSOBY}

Přestože právo určuje, komu bude přiznána způsobilost mít v mezích právního řádu práva a povinnosti (právní osobnost), a kdo tedy je osobou v právním slova smyslu, není toto určení libovolné. Právní osobnost vždy náleží člověku. ,Každý člověk má vrozená, již samotným rozumem a citem poznatelná přirozená práva, a tudiž se považuje za osobu. "21 Tuto jeho právní vlastnost mu jako základní právo zabezpečuje čl. 5 Listiny základních práv a svobod (,,Každý je zpưsobilý mít práva. “). Také mezinárodní dokumenty jednoznačně stanoví, že každý má právo na to, aby byla všude uznávána jeho právní osobnost. 22

Člověk, fyzická osoba, je subjektem práva od svého narození do své smrti, způsobilost mít práva a povinnosti má celý život. Vzniká v zásadě narozením a zaniká smrtí fyzické osoby. Způsobilost mít práva se vztahuje na každou lidskou bytost, nikomu nesmí být znemožněno, aby se stal subjektem práva. Tato způsobilost nemůže být také žádným způsobem omezena, má ji i ten, kdo není svéprávný. Je to nezadatelné a nezcizitelné přirozené právo, kterého se fyzická osoba nemůže vzdát a ani ho nemůže být zbavena ( 19 odst. 2 občanského zákoníku). Každý člověk, bez ohledu na jeho případné fyzické nebo duševní omezení, je vždy subjektem práva, nikoli jeho objektem. ${ }^{23}$

Některá práva vznikají již samotným narozením člověka, např. fyzická osoba je od narození subjektem základních práv a svobod (je jí zaručeno právo na život, nedotknutelnost osoby a její soukromí, lidská důstojnost, právo na osobní čest, dobrou pověst apod.), vzniká jí právo na poskytování bezplatné zdravotní péče ${ }^{24}$ právo mít cestovní doklad, ${ }^{25}$ právo být stavebníkem, ${ }^{26}$ právo a povinnost užívat jméno, ${ }^{27}$ právo na státní občanství České republiky ${ }^{28}$ apod.

21 Srov. § 19 občanského zákoníku, podle jeho § 23 „, [č]lověk má právní osobnost od narozeni až do smrti “.

22 Srov. čl. 16 Mezinárodního paktu o občanských a politických právech, čl. 6 Všeobecné deklarace lidských práv.

23 PRÁŠKOVÁ, K právnímu postavení právnických osob, s. 77.

24 Srov. čl. 31 Listiny základních práv a svobod, § 11 odst. 1 písm. d) zákona č. 48/1997 Sb., o veřejném zdravotním pojištění.

25 Podle $\$ 17$ odst. 1 zákona č. 329/1999 Sb., o cestovních dokladech, ,, [o]bčanovi se vydá cestovní doklad, pokud $k$ tomu jsou splněny podmínky stanovené tímto zákonem nebo mezinárodní smlouvou “, podle $§ 61$ odst. 1 zákona č. $625 / 1999$ Sb., o azylu, ,, [a]zylantovi vydá ministerstvo na žádost cestovní doklad, který je veřejnou listinou ".

26 Podle $\S 2$ odst. 2 písm. c) zákona č. 183/2006 Sb., o územním plánování a stavebním řádu (stavební zákon), stavebníkem se rozumí ,osoba, která pro sebe žádá vydání stavebního povolení nebo ohlašuje provedeni stavby, terénni úpravy nebo zařizení, jakož i její právní nástupce, a dále osoba, která stavbu, terénni úpravu nebo zařizeni provádi, pokud nejde o stavebního podnikatele realizujicího stavbu $v$ rámci své podnikatelské činnosti; stavebnikem se rozumi též investor a objednatel stavby“.

27 Podle $§ 77$ odst. 1 občanského zákoníku ,, [k]aždý člověk má právo uživat své jméno v právním styku“, podle $\S 61$ odst. 1 zákona č. 301/2000 Sb., o matrikách, jménu a př́jmení, ,, [f]yzická osoba, které byl matričním úr̆adem vydán matrični doklad, má povinnost uživat v úředním styku jméno, popřipadě jména, která jsou uvedena na tomto matričním dokladu“.

28 Podle $\$ 4$ zákona č. 186/2013 Sb., o státním občanství České republiky, ,, [d]ítě nabývá státní občanství České republiky narozením, je-li v den jeho narozeni alespon̆ jeden z rodičủ státním občanem České republiky“, podle $\S 5$,[s]tátni občanstvi České republiky nabývá narozením i ditě, které se narodi na jejím územi a které by se jinak stalo osobou bez státního občanství (dále jen ,bezdomovec'), pokud jsou oba rodiče dítěte bezdomovci a alespoň jeden z nich má na územi České republiky ke dni narozeni ditěte povolen pobyt na dobu delši než 90 dnů“. 
Jiná práva a povinnosti vyžadují ke svému vzniku vedle narození další právní skutečnosti, které stanoví jednotlivé zvláštní zákony z oboru správního práva.

Takovou skutečností je především dosažení určitého věku. Určení různých věkových hranic pro stanovení oprávnění nebo pro uložení určitých povinností plyne z uznání, že v daném věku je osoba obvykle zralá a tělesně a duševně vyspělá k odpovídajícím právům a povinnostem. Tak např. počátkem školního roku, který následuje po dni, kdy dítě dosáhne šestého roku věku, vzniká právo a povinnost školní docházky v základní škole, ${ }^{29}$ dosažením patnáctého roku věku vzniká povinnost mít občanský průkaz, ${ }^{30}$ branná povinnost vzniká občanovi dnem následujícím po dni, v němž dosáhne věku 18 let, a zaniká dnem dosažení věku 60 let, ${ }^{31}$ dítě mladší 10 let smí na silnici, místní komunikaci a veřejně př́stupné účelové komunikaci jet na jízdním kole jen pod dohledem osoby starší 15 let; ${ }^{32}$ od okamžiku dosažení stanoveného věku podle zákona o důchodovém pojištění vzniká nárok na starobní důchod apod.

Dalšími podmínkami pro vznik práv a povinností může být státní občanství (např. brannou povinnost nebo volební právo má státní občan České republiky), národnost (např. příslušník národnostní menšiny, která tradičně a dlouhodobě žije na území České republiky, má právo na užívání jazyka národnostní menšiny v úředním styku a před soudy, právo na výchovu a vzdělávání ve svém mateřském jazyce ve školách), ${ }^{33}$ př́padně postavení osoby (např. akademická práva a akademické svobody mohou mít pouze studenti vysoké školy nebo akademičtí pracovníci, zdravotnické služby je povinen poskytovat jen zdravotnický pracovník, povinnost rádné údržby stavby má její vlastník).

\section{PRÁVNICKÉ OSOBY}

Právnické osoby nemají na rozdíl od fyzických osob právní postavení jako přirozený subjekt. Zjednodušeně řečeno vznik a činnost právnických osob se odvíjejí od vůle a jednání ,za nimi stojících“ fyzických osob, jejich účel a jejich kvalifikaci jako subjektu práva nelze dovodit z nich samotných. Někdy se hovoří o tom, že existence právnických osob představuje prodloužení svobody lidí sdružovat se, provádět činnosti společně, prosazovat určité zájmy apod. Koncepce postavení právnických osob v našem občanském zákoníku se hlásí k teorii fikce. Na rozdíl od teorie reality, která vychází z názoru, že právnické osoby reálně existují a že právo tuto skutečnost jen bere na vědomí, teorie fikce považuje za jediný reálně existující typ osoby v právním smyslu jen osobu fyzickou, protože pouze člověk má přirozený a neodvozený vlastní zájem a svobodnou vůli. Právnické osoby jsou podle teorie fikce umělými útvary s právem přiznanou právní osobností. Občanský zákoník vychází z neexistence přirozeného práva právnické osoby na její právní osobnost. Považuje pouze za věc státu, přizná-li různým

29 Srov. § 36 zákona č. 561/2004 Sb., o předškolním, základním, středním, vyšším odborném a jiném vzdělávání (školský zákon).

30 Srov. § 2 odst. 3 zákona č. 328/1999 Sb., o občanských průkazech, ,, [o]bčanský průkaz je povinen mít občan, který dosáhl věku 15 let a má trvalý pobyt na území České republiky. Občanský pri̊kaz může mit i občan, jehož svéprávnost byla omezena. “

31 Srov. § 2 odst. 1 zákona č. 585/2004 Sb., o branné povinnosti a jejím zajištování (branný zákon).

32 Srov. § 58 odst. 2 zákona č. 361/2000 Sb., o provozu na pozemních komunikacích (silniční zákon).

33 Srov. § 9 a 11 zákona č. 273/2001 Sb., o právech př́slušníků národnostních menšin. 
entitám způsobilost mít práva a povinnosti. Právnická osoba nemůže existovat jako subjekt práva sama od sebe, ale jen díky zákonu. ${ }^{34}$

Podle $\S 20$ odst. 1 občanského zákoníku je ,,právnická osoba organizovaný útvar, o kterém zákon stanoví, že má právní osobnost, nebo jehož právní osobnost zákon uzná. Právnická osoba může bez zrèetele na předmèt své činnosti mít práva a povinnosti, které se slučují s její právní povahou. “ Tím se právní postavení právnických osob zásadně liší od právního postavení lidí. Jejich právní status lze tedy označit za odvozený.

Způsobilost mít práva a povinnosti, způsobilost $\mathrm{k}$ právním jednáním a způsobilost deliktní spadají u právnické osoby vjedno a jsou spojeny s existencí právnické osoby, tyto typy způsobilosti má právnická osoba od okamžiku svého vzniku až do svého zániku. ${ }^{35}$ Vznik a zánik právnické osoby upravuje zákon. Pokud se zapisují do obchodního rejstříku, vznikají teprve tímto zápisem a zanikají výmazem z tohoto rejstř́iku. Některé právnické osoby vznikají a zanikají př́mo ze zákona (např. vysoké školy) nebo jiným způsobem, pokud tak zákon stanoví.

Soukromoprávní subjektivita právnických osob je podle § 20 odst. 1 občanského zákoníku generální (právnická osoba může bez zřetele na předmět své činnosti mít práva a povinnosti, které se slučují s její právní povahou). Byla tedy opuštěna doktrína , ultra vires “, podle které právnické osoby mohou mít práva a povinnosti jen v rámci předmětu své činnosti. Generální způsobilost právnických osob je tak omezena jen právní povahou právnické osoby (týká se zejména práv a povinností vyplývajících z rodinněprávních vztahů, některých práv spojených s ochranou osobnosti apod.), nebo může být omezení stanoveno v občanském zákoníku nebo v jiných zákonech. ${ }^{36}$

Právní rád právnickou osobu nedefinuje a neurčuje komplexně její znaky. To je úkolem právní nauky. Existuje nepřeberné množství teoretické literatury zabývající se fenoménem právnických osob, někteří autoři rezignují na definici právnické osoby, jiní pouze zařazují právnickou osobu mezi osoby v právním smyslu a popisují rozdíly mezi osobami fyzickými a právnickými, další se pokoušejí vystihnout podstatu právnické osoby z různých (i neprávních) hledisek. ${ }^{37}$

S určením, jaký útvar je, či není právnickou osobou, souvisí problém různých institucí, faktických entit, které nejsou právnickou osobou, a kterým přesto právní normy přiznávají práva a ukládají povinnosti. Př́íkladů v našem právním řádu můžeme nalézt poměrně hodně.

34 PRÁS̆KOVÁ, K právnímu postavení právnických osob, s. 84-85.

35 Srov. GERLOCH, A. Teorie práva. 8. aktual. vyd. Plzeň: Vydavatelství a nakladatelství Aleš Čeněk, 2021, s. 126: „Pro právnické osoby neplati dělená právní způsobilost, maji dnem svého vzniku způsobilost k právìm a povinnostem, právnímu jednání, právni odpovědnosti. “

36 Srov. např. ZOULÍK, F. Právnické osoby. In: DVOŘÁK, J. - ŠVESTKA, J. - ZUKLÍNOVÁ, M. a kol. Občanské právo hmotné. 1, dil první, Obecná část. Praha: Wolters Kluwer ČR, 2016, s. 269-270.

37 Shrnutí např. v dílech HURDÍK, J. Právnické osoby: obecná právní charakteristika. Brno: Masarykova univerzita, 2000; HURDÍK, J. Právnické osoby a jejich typologie. 2. vyd. Praha: C. H. Beck, 2009; BERAN, Pojem osoby v právu; FRINTA, O. Právnické osoby. Praha: Univerzita Karlova v Praze, Právnická fakulta, 2008; BERAN - ČECH - DVOŘÁK - ELISCHER - HRÁDEK - JANEČEK - KÜHN - NOVOTNÁ KRTOUŠOVÁ - ONDŘEJEK, $c . d$. 
Tato situace není jevem jen současné doby. Na jeden př́klad z nedávné historie upozornil V. Mikule, ${ }^{38}$ týkal se postavení politických stran v předválečném období až do roku 1990. Politické strany tehdy neměly status právnické osoby, ${ }^{39}$ přsto jim zákony ukládaly povinnosti (např. povinnost složit zálohu na úhradu nákladů spojených s rozmnožením kandidátních listin a povinnost $\mathrm{k}$ náhradě celého nákladu, jestliže $\mathrm{v}$ žádném volebním kraji nezískala mandát). Nejvyšší správní soud k tomu vyslovil, že „,predpisy dosavadních zákonů dlužno vykládat jen tak, jak znějí, tj. že se politickým stranám jako útvarům existujícím v zásadè jen fakticky přiznávají jen ona práva a ukládají jen ony závazky, jež zákon stanoví, takže ve všech ostatnich relacích zůstávají i nadále nezpưsobilými státi se subjekty práv a závazkủ." 40

Typickým př́ípadem, kdy právní normy ukládají povinnosti fakticky existujícímu útvaru, který není právnickou osobou, jsou správní úřady. V literatuře i soudní judikatuře byly vysloveny různé názory na jejich povahu a postavení - od chápání správních úřadů jako právnických osob až po dnes naprosto převažující závěr, že se nejedná o právnickou osobu, samostatný právní subjekt, ale o organizační složky státu (o orgány státu), které za stát jednají. Podobná situace je u dalších orgánů veřejné správy i u organizačních jednotek právnických osob. ${ }^{41}$ Např. podle zákona o archivnictví mají povinnost uchovávat dokumenty a umožnit výběr archiválií organizační složky státu a organizační složky územních samosprávných celkủ, ${ }^{42}$ orgán veřejné správy nesmí př̀i výkonu veřejné moci bez ospravedlnitelných důvodů narušit hospodářskou soutěž zejména tím, že zvýhodní určitého soutěžitele nebo skupinu soutěžitelů, vyloučí určitého soutěžitele nebo skupinu soutěžitelů z hospodářské soutěže nebo vyloučí soutěž na relevantním trhu. ${ }^{43}$ Uvést lze i povinnosti uložené správcům, zpracovatelům a př́ijemcům osobních údajů, přičemž se za ně považují mj. též orgány veřejné moci. ${ }^{44}$

$\mathrm{S}$ různými jednotkami, které nejsou osobami, ale mají práva a povinnosti, se lze setkat ve finančněprávních vztazích. Např. § 17 odst. 1 zákona č. 586/1992 Sb., o daních z př́ijmů, stanoví, že poplatníkem daně z př́ijmů právnických osob je mj. organizační složka státu, podílový fond apod. Ustanovení § 4b odst. 2 zákona č. 235/2004 Sb., o dani z přidané hodnoty, stanoví, že ,,[p]ro účely tohoto zákona se na svěrenský fond a organizační složku státu, která je účetní jednotkou, hledí jako na právnickou osobu“.

38 Srov. MIKULE, V. K vývoji právní subjektivity politických stran. Časopis pro právní vědu a praxi. 1997, roč. 5 , č. 3 , s. 372 .

39 Dnes jsou právnickými osobami podle $\S 3$ odst. 1 zákona č. 424/1991 Sb., o sdružování v politických stranách a hnutích.

40 Srov. Boh. 6684/1927, Boh. 7190/1928, nález volebního soudu ze dne 8. 2. 1928, č. 47, Kosch. 191/IV.

41 Srov. § 3 odst. 1 a 2 zákona č. 219/2000 Sb., o majetku České republiky a jejím vystupování v právních vztazích, podle kterých ,,[o]rganizačními složkami státu jsou mj. ministerstva a jiné správní úrúady státu. Organizační složka není právnickou osobou ."; dále napřr. HENDRYCH, D. Organizace veřejné správy. In: HENDRYCH, D. a kol. Správni právo: obecná cást. 9. vyd. Praha: C. H. Beck, 2016, s. 66 a násl.; SLÁDEČEK, V. Obecné správní právo. 4. vyd. Praha: Wolters Kluwer ČR, 2019, s. 261; POUPEROVÁ, O. Ústřední správní úřady - formální, nebo materiální pojetí? Právník. 2013, roč. 142, č. 1, s. 67 a násl.

42 Srov. § 3 odst. 1 písm. a) a g) zákona č. 499/2004 Sb., o archivnictví.

43 Srov. § 19a odst. 1 zákona č. 143/2001 Sb., o ochraně hospodářské soutěže.

44 Srov. čl. 4, odst. 7, 8 a 9 nařízení Evropského parlamentu a Rady (EU) 2016/679, o ochraně fyzických osob v souvislosti se zpracováním osobních údajů a o volném pohybu těchto údajů a o zrušení směrnice 95/46/ES (obecné nařízení o ochraně osobních údajů). 
Dalším známým příkladem je postavení soutěžitele, kterým se podle zákona o ochraně hospodářské soutěže rozumí nejen fyzické a právnické osoby, ale též jejich sdružení a jiné formy seskupování, i když nejsou právnickými osobami. ${ }^{45}$

Občanský zákoník reaguje na případy, kdy jsou práva a povinnosti ukládány někomu (něčemu), kdo není osobou, ustanovením § 17 odst. 2. Podle něj zřídí-li někdo právo nebo uloží-li povinnost tomu, co osobou není, přičte se právo nebo povinnost osobě, které podle povahy věci náleží.

Podobně postupují některé veřejnoprávní předpisy - např. zákon o ochraně hospodářské soutěže ukládá povinnosti soutěžiteli, odpovědnost za jejich porušení je ale vztažena k právnické osobě nebo podnikající fyzické osobě vystupující jako soutěžitel. Podle $\S 42$ odst. 4 a 5 zákona č. 426/2011 Sb., o důchodovém spoření, ,, [d] ůchodový fond nemá právní subjektivitu. Povinnost uložená tímto zákonem di̊chodovému fondu je povinností penzijní společnosti, která jej obhospodařuje. Právo priznané tímto zákonem důchodovému fondu je právem penzijní společnosti, která jej obhospodařuje. Z právnich úkonů vykonaných $v$ souvislosti s obhospodařováním majetku v důchodovém fondu je oprávněna a zavázána penzijní společnost."

\section{ZPƯSOBILOST K PRÁVNÍMU JEDNÁNÍ (SVÉPRÁVNOST)}

Způsobilostí k právnímu jednání se rozumí schopnost vlastním jednáním nabývat práv a plnit povinnosti. Svéprávnost vyjadřuje, kdo je osobou svého práva (sui iuris). Samotná právní osobnost však k tomu, aby subjekt nabyl práva nebo se zavázal k povinnosti, nestačí. Ke vzniku, změně nebo zániku subjektivních práv a povinností musí existovat právní důvod, právní titul. ${ }^{46}$ Právním titulem jsou vedle právních norem právní skutečnosti (právní jednání, konstitutivní rozhodnutí, právně relevantní události). Právní jednání je navenek projevená vůle, která vyvolává právní následky. ${ }^{47}$

Na rozdíl od právní subjektivity, která náleží každé osobě, je ke vzniku způsobilosti k právnímu jednání zapotřebí dosažení potřebné intelektuální a volní vyspělosti, nebot' právní jednání předpokládá rozum a vůli jednající osoby.

\section{FYZICKÉ OSOBY}

Způsobilost fyzické osoby nabývat pro sebe vlastním jednáním práva a zavazovat se k povinnostem se označuje jako svéprávnost. Vzniká postupně podle stavu psychické a rozumové vyspělosti. Protože ve správním právu chybí obecná zákonná

45 Srov. 22 odst. 1 zákona č. 143/2001 Sb., o ochraně hospodářské soutěže: , Soutěžiteli podle tohoto zákona se rozumi fyzické a právnické osoby, jejich sdružení, sdružení těchto sdružení a jiné formy seskupování, a to i v připadě, že tato sdruženi a seskupeni nejsou právnickými osobami, pokud se účastni hospodářské soutěže nebo ji mohou svou činností ovlivňovat, i když nejsou podnikateli. " Soutěžitel je tedy pojmem, který je vykládán a aplikován shodně jako pojem undertaking (podnik) při aplikaci evropského soutěžního práva jako každá jednotka vykonávající hospodářskou činnost bez ohledu na její právní formu a způsob jejího financování. Naopak podle $§ 2972$ občanského zákoníku mohou být soutěžitelem jen fyzické a právnické osoby.

46 Srov. GERLOCH, c. d., s. 157-158.

47 Srov. DVOŘ́K - ŠVESTKA - ZUKLÍNOVÁ, c. d., s. 156 a násl. 
úprava způsobilosti k právnímu jednání, je třeba při určení jejího vzniku vyjít ze zvláštních zákonů upravujících jednotlivé obory veřejné správy a při neexistenci této úpravy použít ustanovení soukromoprávních předpisů, zejména občanského zákoníku.

Plně svéprávným se podle občanského zákoníku stává člověk zletilostí, tj. dovršením osmnáctého roku věku, dř́ve přiznáním svéprávnosti nebo uzavřením manželství. ${ }^{48} \mathrm{Ne}-$ zletilý je způsobilý $\mathrm{k}$ právním jednáním, která jsou svojí povahou přiměřená rozumové a volní vyspělosti nezletilých jeho věku. Tzv. částečná svéprávnost je $\mathrm{v}$ občanském zákoníku konstruována jako vyvratitelná právní domněnka. V zásadě se tedy posuzuje jako způsobilost k právnímu jednání, $\mathrm{k}$ němuž jsou obecně (průměrně) vzato způsobilí nezletilí jeho věku, v konkrétním př́ípadě je však možno prokázat opak. ${ }^{49}$

I pro oblast správního práva lze přiznat osobám mladším osmnácti let způsobilost k takovému právnímu jednání, které je svou povahou přiměřené rozumové a volní vyspělosti odpovídající jejich věku. Zda tomu tak je, by musel posoudit správní orgán podobně jako soud u soukromoprávních jednání. Takových situací nebude zřejmě mnoho. Jedním z důvodů je skutečnost, že správněprávní vztah se vyznačuje nerovným postavením subjektů a nutností prosazovat veřejný zájem, takže je třeba obecně chránit ,slabší“, zranitelnější stranu (nedospělou fyzickou osobu v pozici adresáta veřejné správy) před následky právního jednání, ke kterému by ještě nebyla zcela způsobilá. Kromě toho je nabývání veřejných práv a plnění veřejnoprávních povinností mnohdy spojeno se splněním řady dalších předpokladů a podmínek, které by bylo obtížné pro nezletilého splnit. Některé zvláštní zákony proto výslovně stanoví jako podmínku pro získání určitého oprávnění dosažení věku 18 let. ${ }^{50}$

Protože správní právo neobsahuje žádnou zvláštní úpravu omezení svéprávnosti, vychází se ze soukromoprávních předpisů. Nelze ovšem říci, že omezení svéprávnosti soudem má automaticky význam pro nabývání práv a povinností v oblasti správního práva. Omezení svéprávnosti se vztahuje zpravidla na právní jednání, ze kterého vznikají, mění se nebo zanikají občanskoprávní, rodinněprávní, obchodněprávní a pracovněprávní vztahy, jde tedy o omezení v oblasti soukromoprávních vztahů, a to především majetkových. ${ }^{51} \mathrm{~V}$ rozsudku, jímž dochází $\mathrm{k}$ omezení svéprávnosti, musí být výslovně stanoveno, jaká právní jednání nelze platně činit, ohledně ostatních typů právních jed-

48 Podle $\S 3$ odst. 2 zákona č. 155/1995 Sb., o důchodovém pojištění, plná svéprávnost v právních vztazích pojištění vzniká též přiznáním invalidního důchodu. Způsobilost být účastníkem řízení o přiznání invalidního důchodu vzniká ukončením povinné školní docházky.

49 Srov. $\S 30$ odst. 1 a 2 a $\S 31$ občanského zákoníku. Srov. např. FRINTA, O. Osoby fyzické. In: DVOŘÁK, J. - ŠVESTKA, J. - ZUKLÍNOVÁ, M. a kol. Občanské právo hmotné. 1, dil prvni, Obecná část. 2. aktual. a dopl. vyd. Praha: Wolters Kluwer ČR, 2016, s. 222; nález Ústavního soudu ze dne 8. 1. 2019, sp. zn. IV. ÚS 1639/18.

50 Např. podle $\S 6$ odst. 1 písm. a) zákona č. 455/1991 Sb., živnostenský zákon, je všeobecnou podmínkou provozování živnosti fyzickými osobami plná svéprávnost. Podobně např. $\S 8$ odst. 6 písm. a) a b) zákona č. 99/2004 Sb., o rybářství; § 14a odst. 1 písm. a) a b) zákona č. 119/2002 Sb., o zbraních; $\$ 6$ odst. 2 písm. a) a b) zákona č. 412/2005 Sb., o ochraně utajovaných informací.

51 Srov. § 55 a násl. občanského zákoníku, § 34 a násl. zákona č. 292/2013 Sb., o zvláštních řízeních soudních. Dále např. rozsudek Nejvyššího soudu ze dne 13. 3. 2003, sp. zn. 22 Cdo 2014/2001; rozsudek Nejvyššího soudu ze dne 27. 9. 2007, sp. zn. 30 Cdo 3398/2007; srov. též SVOBODA, K. Nesporná řizení. III. Praha: C. H. Beck, 2017, s. 47. 
nání se má za to, že svéprávnost osoby je zachována. ${ }^{52}$ Soud však může rozhodnout též o omezení svéprávnosti v oblasti veřejného práva, pokud tak stanoví zákon (např. aktivního a pasivního volebního práva, ${ }^{53}$ podání žádosti o vydání občanského průkazu nebo cestovního dokladu, ${ }^{54} \mathrm{v}$ právních vztazích důchodového pojištění $\left.{ }^{55}\right)$. Naopak způsobilost k právnímu jednání $\mathrm{v}$ souvislosti s uplatňováním některých veřejných subjektivních práv zřejmě omezit vůbec nelze - napřr. výkon petičního práva nebo právo na osobní obhajobu v trestním řízení. ${ }^{56}$ Omezení svéprávnosti může představovat překážku získání a výkonu určitých oprávnění, některé zvláštní zákony totiž vyžadují plnou svéprávnost (např. živnostenský zákon, zákon o rybářství, zákon o zbraních apod.).

Obecná ustanovení občanského zákoníku o svéprávnosti, plné svéprávnosti, omezené svéprávnosti nezletilých a osob, jimž byla svéprávnost omezena rozhodnutím soudu, se uplatní pouze za předpokladu, že normy správního práva nestanoví jinak. V řadě zvláštních zákonů jsou obsaženy různé věkové hranice pro některá právní jednání ve správním právu, např. pro získání řidičského oprávnění pro různé skupiny motorových vozidel, ${ }^{57}$ pro získání zbrojního průkazu, ${ }^{58}$ pro podání žádosti o vydání cestovního dokladu, ${ }^{59}$ pro vyslovení souhlasu s poskytnutím zdravotních služeb ${ }^{60}$ apod. V souvislosti s ukládáním některých veřejnoprávních povinností nezletilým osobám může vzniknout diskuze ohledně schopnosti takových osob je také splnit, vykonávat je (např. uložení poplatkové povinnosti nezletilým). ${ }^{61}$

52 Soud rozhodne např. zda a v jakém rozsahu může osoba samostatně nakládat s finančními prostředky, jaké typy smluv může uzavírat, zda může právně jednat v pracovněprávních vztazích, zda je schopna rozhodovat o vlastní léčbě a o užívání zdravotních služeb, zda může uzavřít manželství, vykonávat rodičovskou odpovědnost, pořizovat pro případ smrti apod.

53 Srov. § 2 písm. b) zákona č. 247/1995 Sb., o volbách do Parlamentu České republiky; $§ 4$ odst. 2 písm. b) zákona č. 130/2000 Sb., o volbách do zastupitelstev krajů; § 4 odst. 2 písm. b) zákona č. 491/2001 Sb., o volbách do zastupitelstev obcí, kde omezení svéprávnosti k výkonu volebního práva je považováno za překážku výkonu volebního práva. Srov. též nález Ústavního soudu ze dne 12. července 2010, sp. zn. IV. ÚS 3102/08; usnesení Nejvyššího správního soudu ze dne 22. 6. 2006, č. j. Vol 29/2006-55.

54 Srov. § 4 odst. 5 zákona č. 328/1999 Sb., o občanských průkazech; § 17 odst. 8 zákona č. 329/1999 Sb., o cestovních dokladech.

55 Srov. 33 odst. 2 zákona č. 155/1995 Sb., o důchodovém pojištění.

56 Srov. čl. 18 odst. 1 Listiny základních práv a svobod a $\S 1$ a 2 zákona č. 85/1990 Sb., o právu petičním; rozsudek Nejvyššího soudu ze dne 24. 6. 2020, sp. zn. 24 Cdo 850/2020, podle $\S 33$ odst. 1 trestního řádu práva zde uvedená příslušejí obviněnému i tehdy, je-li jeho svéprávnost omezena.

57 Podle $\S 83$ odst. 1 zákona č. 361/2000 Sb., o silničním provozu, lze řidičské oprávnění udělit jen osobě, která dosáhla věku 15 let, jedná-li se o skupinu AM, 16 let, jedná-li se o skupinu A1, 17 let, jedná-li se o skupiny B1 a T, 18 let, jedná-li se o skupiny A2, B, B+E, C1 a C1+E, 21 let, jedná-li se o skupiny C, $\mathrm{C}+\mathrm{E}, \mathrm{D} 1, \mathrm{D} 1+\mathrm{E}, 24$ let, jedná-li se o skupiny A, D a D+E.

58 Podle $\S 19$ zákona č. 119/2002 Sb., o zbraních a střelivu, lze získat zbrojní průkaz pro různé druhy zbraní různých skupin v různém věku. V zásadě lze zbrojní průkaz skupiny $\mathrm{A}, \mathrm{D}$ nebo $\mathrm{E}$ vydat jen osobě starší 21 let, pokud tento zákon nestanoví jinak. Další věkové hranice jsou v závislosti na skupině zbrojního průkazu stanoveny na 15,16 a 18 let.

59 Srov. § 17 odst. 2 zákona č. 329/1999 Sb., o cestovních dokladech.

60 Srov. § 35 odst. 1 zákona č. 372/2011 Sb., o zdravotních službách.

61 Srov. nález Ústavního soudu ze dne 8. srpna 2017, sp. zn. Pl. ÚS 9/15, publ. pod č. 338/2017 Sb., o zrušení $\S 10$ b odst. 1 písm. a) zákona č. 565/1990 Sb., o místních poplatcích, pro rozpor s ustanoveními Listiny základních práv a svobod a odlišná stanoviska soudců Sládečka, Suchánka a Fialy. 


\section{PRÁVNICKÉ OSOBY}

Je-li způsobilost k právnímu jednání definována jako schopnost vlastním jednáním nabývat práva a plnit povinnosti a právním jednáním se rozumí navenek projevená vůle osoby ke vzniku právního následku (vzniku práva nebo povinnosti) za účelem uspokojení svého zájmu, ${ }^{62}$ pak je otázkou, zda takovou způsobilost právnická osoba má či vůbec může mít.

Odpověd' na tuto otázku, ač je jedním ze stěžejních teoretických i praktických východisek pro postavení právnických osob, není v současné literatuře zcela jednoznačná. ${ }^{63}$ Jedním z názorů je, že právnické osoby mají též způsobilost k právním jednáním (ač není označena jako svéprávnost) a tato způsobilost se kryje s právní subjektivitou (právní osobností). ${ }^{64}$ Podle jiných názorů nemá právnická osoba způsobilost k právnímu jednání, není svéprávná (s argumenty, že zákon právnické osobě, na rozdíl od fyzických osob, svéprávnost nepřiznává, svéprávnost předpokládá rozum a vůli jednajícího, podle $\S 151$ odst. 1 občanského zákoníku za právnickou osobu rozhodují její orgány a nahrazují její vůli). ${ }^{65}$ Důvodová zpráva k občanskému zákoníku z roku 2012 mluví o schopnosti právnické osoby nabývat právním jednáním práva a povinnosti a o tom, že některé právnické osoby mohou být speciálním zákonným režimem v určitých směrech ve svéprávnosti omezeny. ${ }^{66} \mathrm{~K}$ určitému shrnutí výše uvedených názorů a k možným závěrům dospívá novější reprezentativní publikace Právni jednání a odpovědnost právnických osob po rekodifikaci českého soukromého práva: „, Právnická osoba nemůže být nikdy svéprávná v obdobném slova smyslu jako svéprávná osoba fyzická. Nikdy totiž nemůže být způsobilá $k$ vlastnímu právnímu jednání, nebot' jí nemůže náležet vlastní rozum a vi̊le. "67 Za právnickou osobu rozhodují a její vůli nahrazují orgány právnické osoby, tedy lidé, fyzické osoby, jejichž rozum a vůle se právnické osobě přičítají. Které orgány, resp. jejich členové, a v jakém rozsahu právnickou osobu zastupují, upravuje obecně $\S 161$ a násl. občanského zákoníku. Hovoří-li se tedy o právním jednání právnické osoby, je tím míněno to, že za právnickou osobu jednají určené fyzické osoby, a toto jejich jednání se (za zákonem stanovených podmínek) právnické osobě přičítá.

Některá právní jednání, jinak podle obecné soukromoprávní úpravy možná, může zákon pro určité právnické osoby vyloučit. Příkladem mohou být společenství vlastníků

62 Srov. např. BERAN - ČECH - DVOŘÁK - ELISCHER - HRÁDEK - JANEČEK - KÜHN - NOVOTNÁ KRTOUŠOVÁ - ONDŘEJEK, $c$. $d$., s. 12, 19 a další.

63 Srov. PRÁŠKOVÁ, K právnímu postavení právnických osob, s. 91 a násl.; RUBAN, R. K právní subjektivitě, povaze a jednání právnických osob. Časopis pro právní védu a praxi. 2013, roč. 21, č. 3 , s. 388 a násl.

64 Srov. ZOULÍK, c. d., s. 270.

65 Srov. HAVEL, B. in: MELZER, F. - TÉGL, P. a kol. Občanský zákoník: velký komentár. Svazek I, § 1-117. Praha: Leges, 2013, s. 272; BERAN, K. Trestní odpovědnost právnických osob z hlediska teorie fikce. Trestněprávní revue. 2014, roč. 13, č. 5, s. 107 a násl.; BERAN, K. Trestní odpovědnost právnických osob z pohledu nového občanského zákoníku. Trestněprávní revue. 2014, roč. 13, č. 7-8, s. 179 a násl.

66 Srov. Vládní návrh na vydání zákona občanský zákoník: důvodová zpráva. Sněmovní tisk č. 362, 6. volební období Poslanecké sněmovny PČR. 2011, s. 622.

67 Srov. BERAN - ČECH - DVOŘÁK - ELISCHER - HRÁDEK - JANEČEK - KÜHN - NOVOTNÁ KRTOUŠOVÁ - ONDŘEJEK, $c$. $d$. 
jednotek, ${ }^{68}$ veřejné vysoké školy ${ }^{69}$ nebo obce. ${ }^{70}$ Podobná situace nastává při vstupu právnické osoby do likvidace (likvidátor činí jen jednání směřující k likvidaci společnosti, nové smlouvy může uzavírat jen za určitých podmínek). ${ }^{71}$ Naopak o omezení způsobilosti právnické osoby jednat nebo o omezení její právní subjektivity nejde $\mathrm{v}$ př́ípadě omezení nebo pozastavení výkonu funkce orgánů právnické osoby např. v souvislosti s nucenou správou (okruh činností vykonávaných právnickou osobou se v zásadě neomezuje). ${ }^{72}$

Výše byl zmíněn problém stanovení práv a povinností někomu, kdo není právnickou osobou. $\mathrm{V}$ př́padě jednání za právnickou osobu lze zmínit případ, kdy jménem právnické osoby lze jednat již před jejím vznikem. ${ }^{73}$ Podle $§ 127$ občanského zákoníku ,,je $z$ takového jednáni ten, kdo takto jedná, oprávněn i zavázán sám. Jedná-li více osob, jsou oprávněny i zavázány společně a nerozdílně. Právnická osoba mũže účinky těchto jednáni pro sebe do tř́ měsiců od svého vzniku převzit. V takovém př́padě platí, že je z těchto jednáni oprávněna i zavázána od počátku. Převezme-li je, dá dalším zúčastněným najevo, že tak učinila. " Tuto právní úpravu jednání tzv. předběžné společnosti však nelze bez dalšího vztáhnout na právní jednání v oblasti veřejného práva. Např. podle $\S 10$ zákona č. 455/1991 Sb., živnostenský zákon, je stanoveno, že oprávnění provozovat živnost vzniká $\mathrm{v}$ zásadě právnickým osobám již zapsaným do obchodního nebo obdobného rejstř́ku.

Naopak podobnou právní konstrukci tzv. předběžné společnosti jako v $§ 127$ občanského zákoníku lze nalézt v zákoně č. 250/2016 Sb., o odpovědnosti za přestupky ř́zení o nich (dále jen „přestupkový zákon“). Po vzoru zákona o trestní odpovědnosti právnických $\operatorname{osob}^{74}$ je v $\S 20$ odst. 4 upraveno pachatelství právnické osoby, ,jestliže kjednání fyzické osoby, která se za účelem posuzování odpovédnosti právnické osoby za přestupek považuje za osobu, jejiž jednání je pricičitatelné právnické osobě, došlo před vznikem právnické osoby“. Pokud právnická osoba nevznikne, odpovídá za přestupek jednající fyzická osoba.

68 Podle $\S 1194$ odst. 1 občanského zákoníku nesmějí podnikat ani se přímo či neprrímo podílet na podnikání.

69 Podle $§ 20$ odst. 3 zákona č. 111/1998 Sb., o vysokých školách „, [v]eřejná vysoká škola není oprávněna $k$ prevzetí ručení za peněžitý dluh jiné osoby a ke zř́zení zástavního práva k nemovitosti. Veřejná vysoká škola neni oprávněna se stát společníkem veřejné obchodní společnosti nebo komplementárem komanditní společnosti. Dále veřejná vysoká škola neni oprávněna vkládat do obchodni společnosti nebo družstva nemovité věci nabyté do vlastnictví veřejných vysokých škol z vlastnictvi státu, poskytnutý př́spěvek podle $\S 18$ odst. 3 a poskytnutou dotaci podle $\$ 18$ odst. 4. Podmínkou penéžitých a nepenéžitých vkladů do právnických osob je stanoveni pravidel vnitřním předpisem veřejné vysoké školy. "

70 Podle $\S 38$ odst. 3 zákona č. 128/2000 Sb., o obcích, nesmí obec v zásadě ručit za závazky fyzických osob a právnických osob.

71 Srov. zejména $\S 187$ odst. 1, § 188 a 196 odst. 1 občanského zákoníku.

72 Srov. např. § 7a zákona č. 551/1991 Sb., o Všeobecné zdravotní pojišt’ovně České republiky; § 7 zákona č. 280/1992 Sb., o resortních, oborových, podnikových a dalších zdravotních pojišt'ovnách; § 138-143 zákona č. 256/2004 Sb., o podnikání na kapitálovém trhu; § 558-568 zákona č. 240/2013 Sb., o investičních společnostech a investičních fondech; $\S 99$ zákona č. 277/2009 Sb., o pojišt'ovnictví a další.

73 Srov. PRÁŠKOVÁ, K právnímu postaveni právnických osob, s. 88.

74 Podle $\S 8$ odst. 4 písm. a) zákona č. 418/2011 Sb., o trestní odpovědnosti právnických osob a řízení proti nim, se za trestný čin spáchaný právnickou osobou za podmínek stanovených $\S 8$ odst. 1 a 2 se považuje i jednání fyzických osob před vznikem právnické osoby. Blíže k tomu srov. např. ŠÁMAL, P. a kol. Trestní odpovědnost právnických osob: komentár̆. Praha: C. H. Beck, 2012, s. 215 a násl. 


\section{DELIKTNÍ ZPU゚SOBILOST}

Deliktní způsobilost (způsobilost k protiprávnímu jednání) je schopnost být subjektem povinností, které vzniknou v důsledku porušení povinností, schopnost nést odpovědnost za protiprávní jednání.

\section{FYZICKÉ OSOBY}

Deliktní způsobilost fyzické osoby je obecně vázána na dosažení určité rozumové a volní vyspělosti odpovídající zpravidla určitému věku a na zachování schopnosti ovládnout své jednání (volní složka) a schopnosti posoudit jeho následky (intelektuální složka), přičemž obě hlediska musí být splněna současně, a to v době spáchání deliktu.

Přestupkový zákon stanoví v $§ 18$ jako podmínku odpovědnosti za přestupek dovršení patnáctého roku svého věku. Tato věková hranice odpovědnosti za přestupek je shodná s hranicí trestní odpovědnosti. Osobu, která v době spáchání přestupku dovršila patnáctý rok a nepřekročila osmnáctý rok svého věku, označuje přestupkový zákon termínem „mladistvý“ a pro její postih platí zvláštní ustanovení. ${ }^{75}$ Přestupkový zákon obsahuje nové ustanovení (§ 14) reagující na situaci, kdy nesvéprávná osoba (z důvodu nedostatku věku nebo omezení svéprávnosti) není odpovědná za porušení své povinnosti, kterou má jako zvláštní subjekt - nejčastěji jako vlastník určitého statku. Přestupkový zákon pro tento př́pad zavádí odpovědnost zákonného zástupce nebo opatrovníka fyzické osoby, tedy toho, kdo podle zákona má povinnost jednat za zastoupeného.

Druhou podmínkou deliktní způsobilosti fyzické osoby je příčetnost, nikoli plná svéprávnost, jde o dva odlišné pojmy. ${ }^{76}$ Jak bylo výše uvedeno, vztahuje se omezení svéprávnosti v zásadě na oblast soukromoprávních vztahů, navíc jde o omezení způsobilosti k právním, nikoli k protiprávním jednáním. Dủvody vyloučení příčetnosti nejsou shodné s důvody pro omezení svéprávnosti. Proto i plně svéprávné osoby mohou jednat ve stavu nepříčetnosti, a naopak osoby omezené ve svéprávnosti mohou být odpovědné za přestupek. Nedostatek rozpoznávací nebo ovládací schopnosti se posuzuje vždy se zřetelem k povaze spáchaného přestupku. ${ }^{77}$ Pokud ale správní orgán zjistí, že podezřelým je osoba omezená ve svéprávnosti, bude to pro něj signálem pro zjištování, zda nebyla v době činu i nepříčetná ve smyslu $§ 19$ přestupkového zákona. Kromě toho bude mít tato skutečnost význam pro posouzení, zda je taková osoba procesně způsobilá v ř́zení o přsestupku (správním deliktu).

75 Srov. § 55 a násl. přestupkového zákona. Dále např. PRÁŠKOVÁ, H. Odpovědnost mladistvých za správní delikty. In: WINTEROVÁ, A. - DVOŘÁK, J. (eds.). Pocta Sentě Radvanové k 80. narozeninám. Praha: ASPI, 2009, s. 413-423; PRÁŠKOVÁ, H. Rízení o přestupcích mladistvých. In: GŘIVNA, T. ŠIMÁNOVÁ, H. a kol. (eds.). Trestní právo s lidskou tvárí: v upomínku na Marii Vanduchovou. Praha: Wolters Kluwer ČR, 2021, s. 245-258.

76 Srov. § 19 přestupkového zákona. Podrobně k tomu PRÁŠKOVÁ, H. Základy odpovédnosti za správní delikty. Praha: C. H. Beck, 2013, s. 274-278.

77 Pachatel je schopen rozpoznat např. protiprávnost krádeže, nikoli však již složitějšího přestupku jako je přestupek fyzické osoby podle zákona o ochraně hospodářské soutěže, zákona o podnikání na kapitálovém trhu nebo podle zákona o ochraně utajovaných informací. Srov. též např. ŠÁMAL, P. a kol. Trestni zákonik: komentář. I, §-139. 2. vyd. Praha: C. H. Beck, 2012, s. 373, R 17/1979. 
Deliktní způsobilost fyzické osoby jako subjektu přestupku podnikající fyzické osoby není zvláštními zákony upravena. Fyzická osoba odpovídá jako podnikající fyzická osoba pouze tehdy, pokud subjektem přestupku v př́slušné skutkové podstatě přestupku je podnikající fyzická osoba, jednající fyzická osoba je podnikatelem a přestupku se dopustila při svém podnikání nebo v př́mé souvislosti s ním. Určení, zda v konkrétním prrípadě fyzická osoba jednala jako podnikatel, při podnikání nebo v souvislosti s ním, nemusí být jednoduchá. Občanský zákoník za primární kritérium pro rozlišení podnikatele považuje skutečnou povahu činnosti osoby (reálné provozování podnikatelské činnosti naplňující materiální znaky podnikání) a teprve jako druhotné kritérium formální podnikatelský status osoby. ${ }^{78} \mathrm{Z}$ tohoto důvodu lze pro posouzení podmínek deliktní způsobilosti obecně vzato použít analogicky ustanovení $§ 18$ a $\S 19$ přestupkového zákona. Zatímco přestupek fyzické osoby může spáchat tato osoba pouze svým vlastním, osobním jednáním, podnikající fyzická osoba může jednat prostřednictvím zaměstnanců nebo jiných osob. ${ }^{79}$ Jejich protiprávní jednání se pak za stanovených podmínek přičítá podnikající fyzické osobě.

\section{PRÁVNICKÉ OSOBY}

Jak bylo výše uvedeno, zpravidla se uznává, že způsobilost mít práva a povinnosti (právní osobnost), způsobilost k právním jednáním, deliktní způsobilost i procesní způsobilost právnické osoby splývají, ${ }^{80}$ jsou spojeny s její existencí, právnická osoba je má od okamžiku svého vzniku až do svého zániku. Přestupkový zákon sám považuje právnickou osobu za subjekt způsobilý být pachatelem přestupku ( $\$ 20$ přestupkového zákona). Protože právnická osoba jako fiktivní osoba jednat sama nemůže, jedná prostřednictvím oprávněných fyzických osob (orgánů a zástupců právnické osoby). Jejich protiprávní jednání se přičíta za stanovených podmínek právnické osobě. Východisko, že za přestupek odpovídá pouze právnická osoba, která vznikla a existuje, bylo v přestupkovém zákoně nahrazeno širší koncepcí. Podle $\S 20$ odst. 4 přestupkového zákona za přestupek odpovídá i právnická osoba ve fázi svého vzniku, právnická osoba, která sice v souladu se zákonem vznikla, ale soud rozhodl o její neplatnosti, a dále i tehdy, jestliže právní jednání, které mělo založit oprávnění $\mathrm{k}$ jednání za právnickou osobu, je neplatné nebo neúčinné.

Právní řád právnické osobě přiznává deliktní způsobilost, způsobilost být pachatelem přestupku i přes její fiktivní charakter. Jde dokonce ještě dál, když za pachatele pře-

\footnotetext{
78 Podle $\S 420$ odst. 1 občanského zákoníku: „Kdo samostatně vykonává na vlastní účet a odpovědnost výdělečnou činnost živnostenským nebo obdobným zpưsobem se zámèrem činit tak soustavně za účelem dosaženi zisku, je považován se zřetelem k této činnosti za podnikatele. "Podle $§ 421$ odst. 1 se za podnikatele považuje osoba zapsaná v obchodním rejstříku, podle $\S 421$ odst. 2 se má za to, že podnikatelem je osoba, která má $\mathrm{k}$ podnikání živnostenské nebo jiné oprávnění podle jiného zákona. Blíže $\mathrm{k}$ tomu srov. PRÁŠKOVÁ, H. Nové přestupkové právo. Praha: Leges, 2017, s. 160 a násl., dále srov. závěr poradního sboru ministra vnitra ke správnímu řádu a správnímu trestání ze dne 21. 9. 2018, č. 163.

79 Srov. § 22 odst. 2 a 3 přestupkového zákona.

80 Srov. ZOULÍK, c. d., s. 270. Diskusně k tomu např. HAVEL, c. d., s. 272. Srov. např. BERAN, Trestní odpovédnost právnických osob z hlediska teorie fikce, s. 107 a násl.; BERAN, Trestní odpovédnost právnických osob z pohledu nového občanského zákoníku, s. 179 a násl.
} 
stupku označuje entity, které právnickou osobou vůbec nejsou, např. organizační složky státu, organizační složky územních samosprávných celků, orgány veřejné správy. ${ }^{81}$

\section{ZPU゚SOBILOST BÝT ÚČASTNÍKEM ŘÍZENÍ A PROCESNÍ ZPU゚SOBILOST}

Subjektivní práva a povinnosti jednotlivců v oblasti správního práva jsou aplikovány správními orgány v rámci správního řízení. Protože procesní právo je prostředkem k naplnění účelu právních norem a jeho obsahem je vytváření a ochrana hmotných práv, je zrejejmé, že je zde úzká návaznost procesního a hmotněprávního postavení osob.

\section{ZPƯSOBILOST BÝT ÚČASTNÍKEM ŘÍZENÍ}

Způsobilost být účastníkem řízení je schopnost být nositelem procesních práv a povinností; tato způsobilost vyplývá především z hmotného práva. Ten, kdo má v hmotném právu právní osobnost (právní subjektivitu, způsobilost mít práva a povinnosti), je způsobilý mít procesní práva a povinnosti (viz výše). Ten, kdo právní subjektivitu nemá, se může stát účastníkem řízení pouze tehdy, stanoví-li tak zákon, zákon mu tedy musí způsobilost být účastníkem řízení výslovně přiznat. ${ }^{82}$ Okruh účastníků správního řízení je stanoven obecně v $§ 27$ a $§ 28$ správního řádu. Podle toho, v jaké míře se rozhodnutí může dotknout práv a povinností osob, se liší i jejich procesní postavení.

Účastenství jako procesní institut je třeba odlišovat od tzv. věcné legitimace, tj. určení, kdo je podle hmotného práva skutečně nositelem tvrzeného práva nebo povinnosti v konkrétním případě. To, že je řízení zahájeno ve vztahu k určité osobě (bud' na její žádost, nebo vůči ní z moci úřední), ještě nic neříká o tom, zda jí bude po provedeném řízení oprávnění přiznáno nebo povinnost uložena (např. žádost o koncesi podá osoba nesplňující zákonné podmínky, řízení o přestupku bude zahájeno s osobou, která není nebo ani nemůže být pachatelem přestupku). Věcná legitimace se tak projeví až v meritorním rozhodnutí správního orgánu, má však též význam procesní (např. v otázce procesního nástupnictví). ${ }^{83}$

Dojde-li ke ztrátě způsobilosti být účastníkem řízení v průběhu správního řízení, pak (pokud nedojde k procesnímu nástupnictví) je to důvodem pro zastavení řízení, ${ }^{84}$

81 Např. § 22aa odst. 1 zákona č. 143/2001 Sb., o ochraně hospodářské soutěže; § 62 zákona č. 110/2019 Sb., o zpracování osobních údajů; § 74 odst. 6 zákona č. 499/2004 Sb., o archivnictví. Blíže k tomu např. STAŠA, J. Ještě k trestání osob veřejného práva. In: JELÍNEK, J. a kol. Trestni odpovědnost právnických osob: bilance a perspektivy. Praha: Leges, 2013, s. 73 a násl.

82 Podle některých dřívějších zákonů bylo např. přiznáváno postavení účastníka řízení správním orgánům, srov. např. § 82 odst. 4 zákona č. 458/2000 Sb., energetický zákon, ve znění do 3. 7. 2009: „, Ministerstvo je účastnikem územního řizení a dotčeným orgánem při stavebním řizení podle zvláštního právního předpisu. "Současný správní řád vyžaduje, aby účastníky řízení byly „osoby“ (viz $§ 27$ a $\$ 28$ správního řádu).

83 Srov. např. WINTEROVÁ, A. - MACKOVÁ, A. a kol. Civilní právo procesní. Díl první, Řizení nalézací. 9. aktual. vyd. Praha: Leges, 2018, s. 137-138.

84 Srov. $§ 66$ odst. 1 písm. f) a $§ 66$ odst. 2 správního řádu. 
protože není naplněna jedna ze základních procesních podmínek a tento nedostatek nelze odstranit.

\section{PROCESNÍ ZPŮSOBILOST}

Procesní způsobilost označuje schopnost osoby samostatně v řízení před správním orgánem jednat, tedy vykonávat samostatně procesní povinnosti a realizovat procesní práva. Ne každý, kdo má způsobilost být účastníkem řízení, má i procesní způsobilost. Procesní způsobilost je podle $§ 29$ správního řádu tradičně vázána na hmotněprávní svéprávnost (způsobilost k právnímu jednání) s odkazem na ustanovení občanského zákoníku.

Jak bylo již výše uvedeno, tato ustanovení se uplatní pouze za předpokladu, že normy správního práva nestanoví jinak. Je-li někdo podle norem správního práva způsobilý k určitému právnímu jednání v nižším věku, než je obecná hranice plné svéprávnosti (zletilost, tj. dovršení osmnáctého roku věku), pak má v tomto rozsahu též procesní způsobilost. Např. lze-li podle zákona o silničním provozu udělit řidičské oprávnění pro skupinu AM osobě, která dosáhla věku 15 let, může tato osoba samostatně vystupovat v řízení o získání takového řidičského oprávnění. Přestupkový zákon stanoví jako podmínku odpovědnosti za přestupek dovršení patnáctého roku svého věku a prŕíčtnost v době jeho spáchání. Z toho podle $§ 29$ správního řádu plyne, že i mladistvý obviněný má plnou procesní způsobilost a nemusí být zastoupen.

Protože i pro oblast správního práva lze přiznat nezletilým osobám způsobilost k takovému právnímu jednání, které je svou povahou přiměřené rozumové a volní vyspělosti odpovídající jejich věku, je třeba zodpovědět otázku, zda totéž platí také pro samostatné vystupování ve správním řízení. Teorie i praxe se shoduje na názoru, že (soudní i správní) řízení je mnohem komplexnější a komplikovanější proces než samotné právní jednání a nese s sebou významné právní důsledky. Jde o výkon práv a povinností účastníka řízení, tedy např. o právo podávat podání (žádost, důkazní návrhy, opravné prostředky), nahlížet do spisů, klást otázky svědkům apod. a nelze předpokládat, že samostatné vystupování nezletilého před správním orgánem by bylo srovnatelné s jednáním dospělého. ${ }^{85}$ Nezletilé osoby (pokud ze zákona neplyne něco jiného - viz výše) by tak neměly mít plnou procesní způsobilost. Tento závěr je v souladu s potřebou poskytovat ochranu nezletilým dětem. ${ }^{86}$ Ze stejného důvodu je vyloučeno, aby se nezletilá osoba stala zmocněncem, protože je třeba zajistit, aby došlo k řádnému hájení práv účastníků řízení a celkovému zefektivnění řízení. ${ }^{87}$ To nemění nic na tom, že se nezletilé osoby mohou v řízení vyjadřovat $\mathrm{k}$ věci a sdělit správnímu orgánu svůj názor ( $\$ 29$ odst. 4 správního řádu).

\footnotetext{
85 Srov. např. nález Ústavního soudu ze dne 14. 14. 2014, sp. zn. I. ÚS 1041/14.

6 Srov. též čl. 3 Úmluvy o právech dítěte.

87 Srov. např. rozsudky Nejvyššího správního soudu ze dne 23. 2. 2016, č. j. 8 As 6/2016-34, ze dne 29. 3. 2016, č. j. 1 As 33/2016-36, ze dne 17. 8. 2016, č. j. 7 As 79/2016-32; usnesení Nejvyššího správního soudu ze dne 8. 2. 2017, č. j. 2 As 179/2016-56; usnesení Ústavního soudu ze dne 25. 7. 2017, sp. zn. IV. ÚS 3530/2016, závěr poradního sboru ministra vnitra č. 144/2015.
} 
U právnické osoby je institut procesní způsobilosti předmětem diskuse. ${ }^{88}$ Zřejmě převažující je mínění, že u právnických osob se právní subjektivita a svéprávnost nerozlišuje, a proto u nich splývá i způsobilost být účastníkem se způsobilostí procesní. ${ }^{89} \mathrm{Je}$ však třeba řešit otázku, kdo za právnickou osobu v rrízení jedná. ${ }^{90}$ Správní řád upravuje pravidla pro procesní jednání právnických osob $\mathrm{v} \S 30$ odst. 1, podle kterého jménem právnické osoby činí úkony ten, kdo je $\mathrm{k}$ tomu oprávněn $\mathrm{v}$ řízení před soudem podle $\S 21$ občanského soudního řádu. ${ }^{11}$ Ustanovení $\S 30$ odst. 2 a 3 správního řádu pak určuje, kdo činí procesní úkony jménem státu, a dále, kdo činí procesní úkony za územní samosprávný celek. I když se príjetím občanského zákoníku z roku 2012 zcela změnilo pojetí právnických osob a způsob jednání za ně, neovlivňuje tato koncepční změna způsob procesního jednání právnických osob (tzv. koncept př́mého jednání právnických osob)..$^{92}$

\section{ZÁVĚR}

Článek se zabývá právním postavením fyzických a právnických osob ve správněprávních vztazích. Po obecném úvodu jsou postupně rozebrány právní subjektivita, způsobilost $\mathrm{k}$ jednání, deliktní způsobilost, způsobilost být účastníkem řízení a procesní způsobilost v oblasti správního práva. Článek upozorňuje na problémy, které vyvolávají právní úpravy přiznávající práva a ukládající povinnosti faktickým entitám, které nejsou právnickou osobou. Zejména jde o otázku, komu lze taková práva a povinnosti přičíst a kdo nese za jejich realizaci odpovědnost. V oblasti způsobilosti k právnímu jednání fyzických osob může být sporné, zda a do jaké míry přiznat nezletilým tzv. částečnou způsobilost. V článku se dospívá $\mathrm{k}$ závěru, že částečnou způsobilost nezletilého by musel posoudit správní orgán, vzhledem $\mathrm{k}$ charakteru správněprávních vztahů a způsobu nabývání veřejných práv a plnění veřejnoprávních povinností však její přiznání nebude časté. U právnických osob je zásadní otázkou, v jakém smyslu lze u nich hovořit o způsobilosti k právnímu jednání. Vzhledem $\mathrm{k}$ teorii fikce, na které je založena současná právní úprava postavení právnických osob v našem právním řádu, vyjadřuje skutečnost, že za právnickou osobu jednají určené fyzické osoby, a toto jejich jednání se (za zákonem stanovených podmínek) právnické osobě přičítá. V oblasti deliktní způsobilosti vznikají problémy spojené s tím, že některé právní úpravy určují jako pachatele přestupku entity, které právnickou osobou vůbec nejsou. Otázky, které vyvstávají u právní subjektivity a způsobilosti k právnímu jednání, se následně projevují

88 Ke shrnutí diskuse srov. např. DVOŘÁK, B. K problematice procesního jednání právnických osob. Právní rozhledy. 2016, č. 19, s. 649 a násl. a literatura zde uvedená.

89 Srov. např. WINTEROVÁ - MACKOVÁ, c. d., s. 134.

90 Podrobně k tomu srov. PRÁŠKOVÁ, H. Jednání právnických osob ve správním řízení. Právní rozhledy. 2017, č. 22, s. 788 a násl.

91 Zákon č. 99/1963 Sb., občanský soudní řád.

92 Srov. např. KORBEL, F. Komentáŕ k § 21. In: JIRSA, J. a kol. Občanské soudní řizení: soudcovský komentář. Kniha I. Praha: HBT, 2014, s. 128; nález Ústavního soudu ze dne 9. prosince 2003, sp. zn. I. ÚS 554/02, závěr poradního sboru ministra vnitra č. 130/2014. 
také u způsobilosti být účastníkem řízení a procesní způsobilosti fyzických a právnických osob.

Vzhledem k rozsahu článku již nebylo možné rozebrat širokou problematiku veřejných subjektivních práv a veřejnoprávních povinností, které tvoří nedílnou součást statusu jednotlivce ve správním právu. Zde by bylo zajímavé zabývat se zejména vývojovými tendencemi postavení fyzických a právnických osob v oblasti veřejné správy.

doc. JUDr. Helena Prášková, CSc.

Právnická fakulta Univerzity Karlovy

praskova@prf.cuni.cz 